\title{
Corrosive and Mechanical Experimental Tests for Selected Stainless Steel Pipes
}

\author{
Wasilewska Katarzyna ${ }^{1, a^{*}}$, Glinicka Aniela ${ }^{2, \text { b * }}$ \\ ${ }^{1}$ Warszawa, ul. Płużnicka 5c, Poland \\ ${ }^{2}$ Warsaw University of Technology, Faculty of Civil Engineering, Warszawa, L. Kaczyńskiego \\ 16, Poland \\ awasilewska.katarzyna.1@gmail.com, ba.glinicka@il.pw.edu.pl
}

Keywords: Corrosion, Small Diameter Pipes, Stainless Steel, Experimental Studies

\begin{abstract}
The article presents corrosion tests of small diameters pipes made of stainless steel OH17N12M2 chromium - nickel - molybdenum with material number 1.4401 EN 10088 which does not have a pronounced yield point. The samples were subjected to corrosion in a laboratory at room temperature in solutions of sulfuric and hydrochloric acid at specified concentrations and in a given time. Corrosion was observed as surface uniform. As a result of the analysis, the dependences showing the mass loss as a function of time were obtained and the corrosion rate and average speed were determined. Following that, some of the corroded and non-corroded samples were subjected to a bending test in the Instron 3382 testing machine. On the basis of the measurements, plots showing maximum deflection of a beam as a function of bending load were created and compared. It was determined that the samples which were corroded for $720 \mathrm{~h}$ in 5\% $\mathrm{H}_{2} \mathrm{SO}_{4}$ were not corroded and retained the bending capacity. Samples corroded for longer period of time or in more potent acids had the bending capacity reduced which was noted.
\end{abstract}

\section{Introduction}

Use of components made of stainless steel in normal atmospheric conditions does not cause the corrosion of steel they're made of. It's used in construction of bridge elements, buildings, hot water systems, sewage treatment plant elements, elements and constructions in chemical plants $[1,2]$.

Stainless steel can corrode in the event of a failure, for example a sulfuric acid spill or under the conditions of constant operation in aggressive medium in the environment [3].

Let's assume that in a chemical plant there's a bearing construction made of small diameter steel pipes OH17N12M2; for example stairs, lattice, tower, support structure, etc. Let us ask questions that show the purpose of this work. How fast will stainless steel corrode in 5-20\% $\mathrm{H}_{2} \mathrm{SO}_{4}$ and $\mathrm{HCL}$ acid after $720 \mathrm{~h}$ or many times longer. What are the quantitative results of the loss of load bearing capacity when bending small diameter pipes made of stainless steel? Can corroded pipes still be used and if so, how much their use capacity have been reduced.

\section{Corrosion of Stainless-Steel Samples}

Samples accepted for testing were small diameter pipes made of steel OH17N12M2 chromium nickel - molybdenum steel with material number 1.4401 EN 10088 in different diameters. The chemical composition as well as and physical and mechanical properties of this material are given in the standards tables $[4,5]$. Standardized value of tensile strength of this steel is $\mathrm{R}_{\mathrm{m}}=$ $530 \div 680 \mathrm{~N} / \mathrm{mm}^{2}$ and yield strength is $R_{02}=240 \mathrm{~N} / \mathrm{mm}^{2}$. A series of pipes with five different nominal diameters DN [mm] have been prepared, they were as follows: DN15, DN18, DN22, DN28 and DN35. There were 3 samples in each series. 
The dimensions of series of tubular samples, designated for corrosion in sulfuric acid solutions were as follows (diameter $\Phi$, wall thickness g, and length l given in [mm]): DN15: $\Phi 15, \mathrm{~g}=1.2, l=300, l=30$; DN18: $\Phi 18, \mathrm{~g}=1.2, l=300, l=30 ; \mathrm{DN} 22: \Phi 22, \mathrm{~g}=1.2, l=300, l=30$; DN28: $\Phi 28, \mathrm{~g}=1.2, l=300, l=30$; DN35: $\Phi 35, \mathrm{~g}=1,5, l=300, l=30$. The series of tubular samples prepared for corrosion in hydrochloric acid were as follows: DN15, DN18, DN22, DN28, DN35. Wall thickness was the same as in the samples above, length was $l=30 \mathrm{~mm}$. Corrosion tests were carried out for all samples and bending tests for $300 \mathrm{~mm}$ pipes. Stress tests for pipes with length $l$ $=300 \mathrm{~mm}$ were carried out in the Instron 3382 testing. The corrosion process was carried out in the laboratory in acidic solutions, in cuvettes at ambient temperature (Tab 1) Corrosion time was set based on the literature (shortest time was 360h); a detailed description is available in the paper. Some of the cuvettes with corroding samples were placed under a vent and some were not. In the first case the acid concentration varied, but in the second case it was stable. Before the corrosion process, samples were weighed; after, they were dried and weighed again.

Table. 1. List of corrosion times and corrosive environments.

\begin{tabular}{|l|l|}
\hline Corrosive environments & Corrosion times [h] \\
\hline $20 \%$ sulfuric acid, cuvette under a vent & $720,1228,1704,2208=$ tk \\
\hline $5 \%$ sulfuric acid, cuvette under a vent & 720 \\
\hline $5 \%$ sulfuric acid, open cuvette & 720 \\
\hline $20 \%$ hydrochloric acid, open cuvette & 720 \\
\hline
\end{tabular}

The corrosion was assessed macroscopically as being uniform on surface on both inner and outer surfaces. After the measurements, the rate of the mass and the linear corrosion $[3,7]$ for each diameter of a pipe (Fig 1) were calculated. The average rate of corrosion was also calculated.
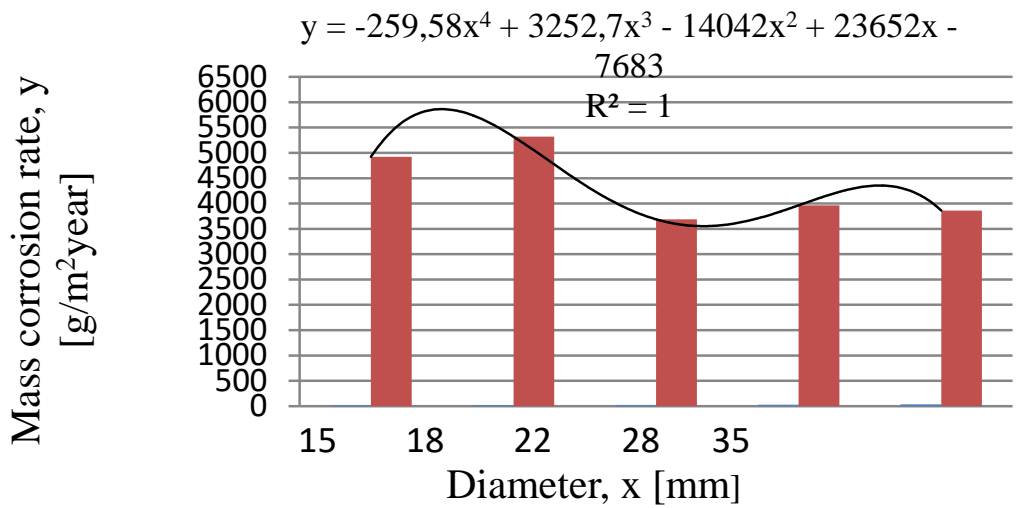

Fig. 1. Polynomial dependence, rate of corrosion - pipe diameter; $20 \% \mathrm{H}_{2} \mathrm{SO}_{4}$

Average velocity of linear $V$ corrosion, which does not vary with diameters, is: in $20 \% \mathrm{H}_{2} \mathrm{SO}_{4}$ - $V=0,53$ [mm/year], in $5 \% \mathrm{H}_{2} \mathrm{SO}_{4}$ under the extract $V=0,13$ [mm/year], in 20\% HCL - $V=0,19$ [mm/year].

Statistical evaluation of the linear corrosion rate was carried out using Student's t-distribution [8]. Given $n=20$ average values of linear corrosion rate measurements of stainless-steel samples corroded with $20 \%$ sulfuric acid, the mean value of $X=0.53$ was obtained; and uncertainty of the mean value $S_{X t}=0,052$. Whereas, from the series of $n=5$ average values of linear corrosion rates of stainless-steel samples corroded in $20 \%$ hydrochloric acid, we obtained: $X=0,19 ; S_{X t}=0,056$ 
The results of corrosion tests acquired after $720 \mathrm{~h}$ lead to following conclusions:

1. The corrosion process in a $5 \% \mathrm{H}_{2} \mathrm{SO}_{4}$ in an open cuvette has not happened, so it is a safe environment.

2. Corrosion process in 5\% sulfuric acid solution under a vent happened, the vent caused evaporation of distilled water (even though the water was being added during the experiment) so the acid concentration could've changed. It is not a safe environment.

3. Corrosion processes were most intense in $20 \%$ sulfuric and hydrochloric acid solutions, so they are considered dangerous environments.

4. When corrosion time was longer, than appropriately longer than $720 \mathrm{~h}$, the loss of mass of the pipes was significantly higher. The amount of the loss was dependent on the acid concentration and length of corrosion.

5. Loss of mass shows non-linear dependency on the pipe's diameter. For applicability purposes, average values were calculated [9].

\section{Bending Tests for Corroded Tube Samples}

On the basis of axial tensile tests of non-corroded and corroded pipes in the Instron testing machine, it was determined that corrosion did not affect the Young's modulus E, yield stress threshold $R_{02}$, elongation threshold $u_{02}$, nor tensile strength $R_{m}$. It did decrease the elongation $\mathrm{u}_{\mathrm{om}}$ and cross-section of samples [6].

This chapter presents the results of bending tests under static load performed in an Instron 3382 testing machine; Fig. 2 and Fig. 3. The samples were secured against bending via appropriate supports. The traverse speed of the machine was $5 \mathrm{~mm} / \mathrm{min}$ and the frequency of data collection was 5 points/sec. Bending tests were performed on stainless steel pipes corroded in a $5 \%$ strength sulfuric acid under the extract for 720 hours, in a 20\% strength sulfuric acid solution for 720 hours and in a 20\% sulfuric acid solution for 2208 hours (tk - end time). Non-corroded pipes with the same dimensions were also bent. The measurements were made on pipes with diameters: DN22, DN28, DN35. The spacing of support beams was set to $250 \mathrm{~mm}$. The measurements were carried out for 36 samples. This gives the opportunity to quantitatively assess the loss of bearing capacity $[9,10,11]$. Compression tests of short stainless-steel pipes corroded are described in [12].

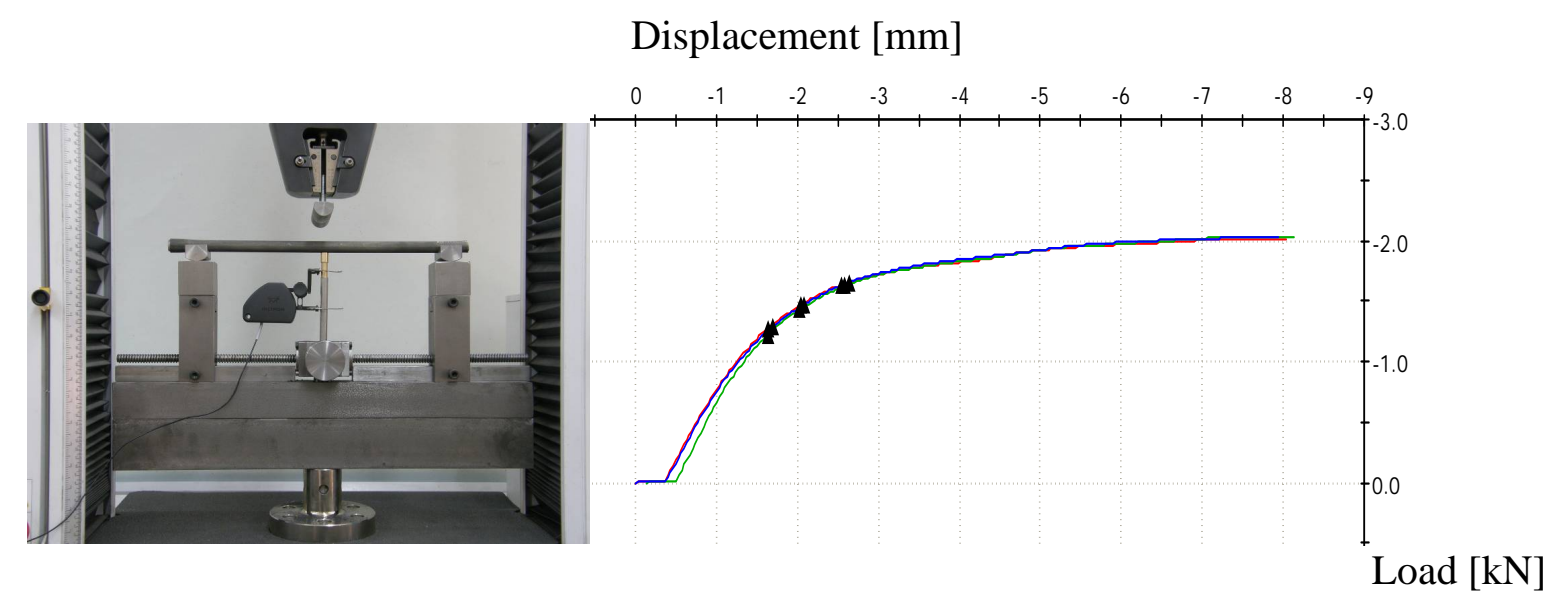

Fig. 2. Bending test of corroded pipe. Fig. 3. Load-displacement curves for 3 bending pipes DN22, which were corroded in $20 \%$ sulfuric acid for $720 \mathrm{~h}$. 
The software of the testing machine was called BlueHill [13] and was used to parse and compile the measurement results. On the plots depicting vertical displacement in the middle of a beam (deflection arrow) in relation to the load, which can be received with the BlueHill software, three characteristic points were selected for reading, namely: point 1 - corresponding to $33 \%$ of the load curve slope - deflection arrow, point 2 - corresponding to $50 \%$ of the tilt threshold, and point 3 - corresponding to $67 \%$ of the tilt threshold; Fig. 3 . The load values and the deflection arrows were read from these graphs at the end of the linear section of the graph. The type of destruction of all the samples was the same, i.e. the first phase was characterized by a deformation of the upper wall followed by the second phase - the permanent destruction of the bottom edge. Fig. 4 plots show a relation between load and deflection arrow for tested beams. Based on the measured load values, the values of the relative decrease of the bearing capacity

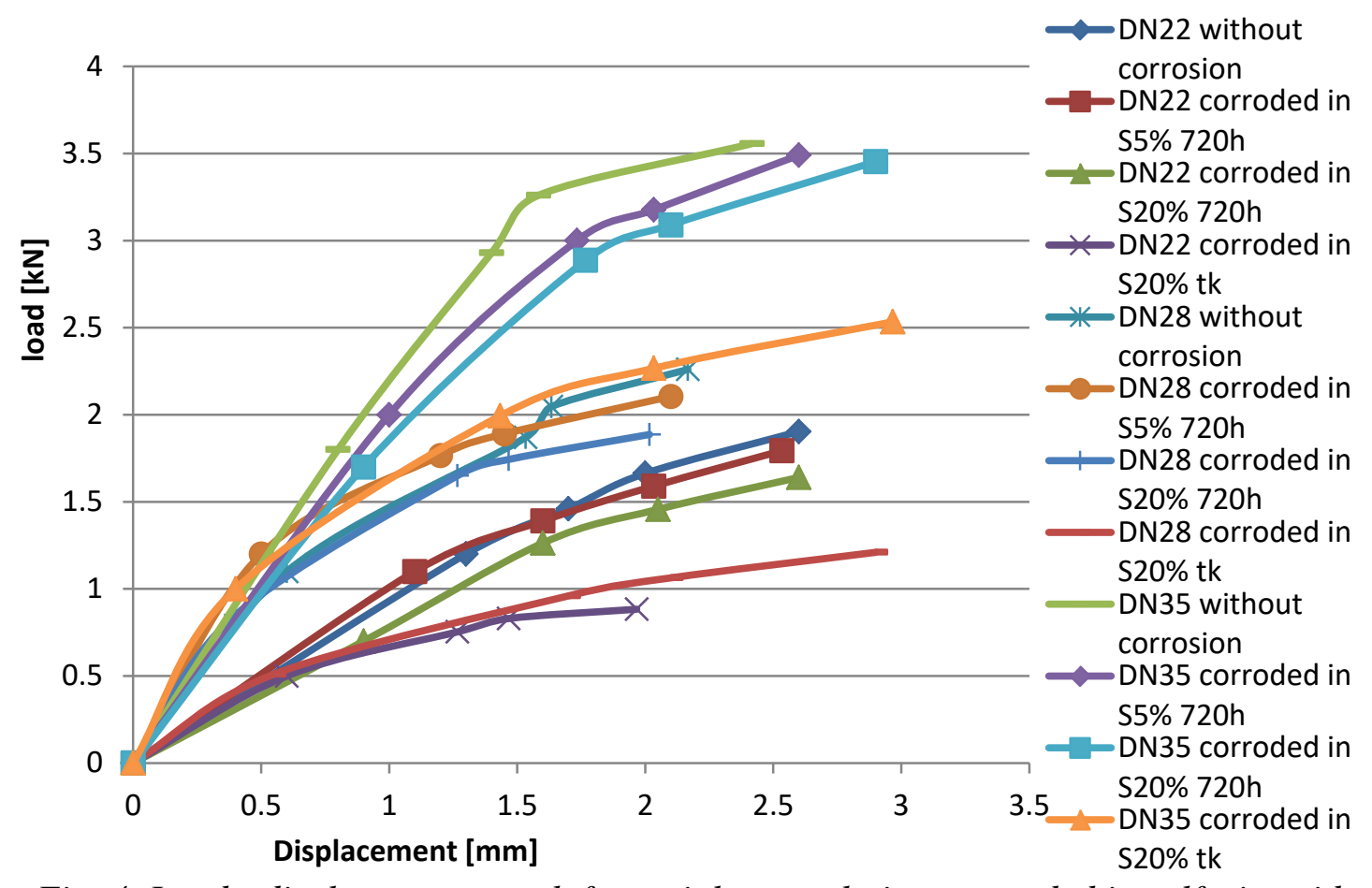

Fig. 4. Load - displacement graph for stainless steel pipes corroded in sulfuric acid and noncorroded.

transferred by corroded pipes in the points 1 to 3 and at the end of the linear section were calculated, and the results obtained are listed in tab. 2 .

The drop of bearing capacity at the boundary of the linear section after corrosion of the pipe in 5\% sulfuric acid for 720 hours was very low. The longer the sample corrosion time and the higher the sulfuric acid concentration, the lower the bearing capacity. The large value of bearing capacity decrease was recorded when stainless-steel pipes corroded for 2208 h (92 days) in 20\% sulfuric acid. After the analysis carried out in [6], it was found that corrosion did not affect the Young's modulus E, tensile strength and the yield stress of the material. However, it decreased the cross-section of the samples.

The decrease equal zero of EJ $\mathrm{y}_{\mathrm{y}}$ occurred when the DN28 stainless steel pipes corroded for 30 days in 5\% sulfuric acid and the DN22 pipes corroded for 30 days in 5\% and in 20\% sulfuric acid. 
Table 2. Comparison of the relative load decrease in corroded bent pipes according to measurements.

\begin{tabular}{|l|c|c|c|c|}
\hline \multicolumn{1}{|c|}{ Corrosion } & $\begin{array}{c}\text { Relative load drop } \\
\text { at the end of the } \\
\text { linear section [\%] }\end{array}$ & $\begin{array}{c}\text { Relative } \\
\text { load drop } \\
\text { point 1 [\%] }\end{array}$ & $\begin{array}{c}\text { Relative load } \\
\text { drop } \\
\text { point 2 [\%] }\end{array}$ & $\begin{array}{c}\text { Relative load } \\
\text { drop } \\
\text { point 3 [\%] }\end{array}$ \\
\hline DN22, sulfuric acid 5\% 720 h & 8 & 5 & 4 & 6 \\
\hline DN22, sulfuric acid 20\% 720 h & 42 & 14 & 12 & 14 \\
\hline DN22, sulfuric acid 20\% tk & 58 & 49 & 50 & 54 \\
\hline DN28, sulfuric acid 5\% 720 h & - & 5 & 8 & 7 \\
\hline DN28, sulfuric acid 20\% 720 h & 23 & 12 & 15 & 16 \\
\hline DN28, sulfuric acid 20\% tk & 54 & 49 & 48 & 46 \\
\hline DN35, sulfuric acid 5\% 720 h & - & - & 2 & 2 \\
\hline DN35, sulfuric acid 20\% 720 h & 6 & 1 & 5 & 3 \\
\hline DN35, sulfuric acid 20\% tk & 44 & 32 & 30 & 29 \\
\hline
\end{tabular}

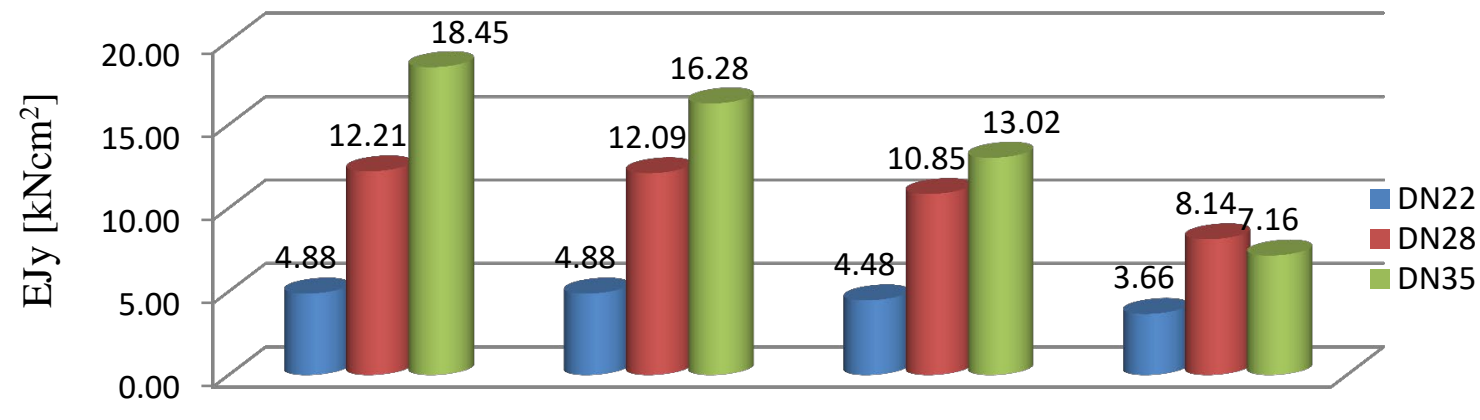

without corrosion sulfuric acid $5 \% 720 \mathrm{~h}$ sulfuric acid $20 \% 720 \mathrm{~h}$ sulfuric acid $20 \%$ tk

Fig. 5. The effect of corrosion on the EJ $J_{y}$ coefficient.

\section{Conclusions}

The summary presents the conclusions from corrosion tests and mechanical tests of stainless steel samples. To sum up analysis of the results of corrosion effects, carried out in the laboratory, on small-diameter pipes, it was found that:

1. corrosion that occurred was determined to be surface uniform; rate of corrosion is dependent on the exact diameter of the corroded pipe,

2. stainless steel is resistant to $5 \%$ sulfuric acid, but is not very resistant to $5 \%$ sulfuric acid under a vent (because its concentration may have increased), it is not resistant to 20\% hydrochloric acid and 20\% sulfuric acid. Because of this, only pipes made of stainless steel corroded in $5 \%$ sulfuric acid after 720 hours are suitable for use,

3. In the final effects, average corrosion rates have been calculated for corroded stainless steel pipes.

4. The results were statistically based on the Student's t distribution. The lowest uncertainty in the average value of the corrosion rate was obtained for corrosion of samples corroded in $20 \%$ sulfuric acid, 
5. The most important factor impacting the loss of pipe mass was the type of corrosive environment and the time of contact of the pipes with this environment.

Summing up the analysis results of the bending tests of beams with circular cross-section, performed in the strength testing machine, it can be concluded that:

1. There were no differences in the shapes of damaged corroded and non-corroded pipes in bending tests,

2. The values of the drop of bearing capacity when bending corroded pipes were assessed,

3. Extending corrosion time caused an increase in the relative drop in bearing capacity at selected points of measurement,

4. The reduction of the bending stiffness EJy was determined at an individual corrosion rate.

Stainless steel, thanks to its chemical composition, protects structural elements from atmospheric corrosion and from corrosion caused by $5 \%$ sulfuric acid for 720 hours, but does not protect against acids with higher concentrations.

\section{References}

[1] G. Lagoda: Wiadukty nad autostradami, Wybrane zagadnienia kształtowania konstrukcyjnego i estetycznego. OW PW Warszawa (2001).

[2] P.Grzesiak, R.Motława, Korozja stali w kwasie siarkowym. Instytut Ochrony roślin, PIB, Poznań (2008).

[3] P.R. Roberge: Corrosion Engineering. Principle and Practice. McGraw-Hill, USA (2008).

[4] PN-EN 10155:1997 + Apl: (2003): Skład chemiczny i wybrane własności mechaniczne stali konstrukcyjnych trudno rdzewiejących.

[5] PN-EN 10088-1. Stale odporne na korozję - część 1.Gatunki stali odpornych na korozję.

[6] K. Wasilewska: Wpływ korozji na nośność wybranych elementów stosowanych w sieciach komunalnych, Rozprawa doktorska. PW, Warszawa (2014).

[7] S.D. Cramer, B.S. Covino (ed.), Corrosion: Environments and Industries, Handbook, Volume 13, ASM International (2006).

[8] H. Szydłowski: Teoria pomiarów, PWN, Warszawa (1981).

[9] A. Glinicka, C. Ajdukiewicz, S. Imiełowski, Effects of uniformly distributed side corrosion on thin-walled open cross-section steel columns. Roads and Bridges, 159 (2016), pp. 257 - 270. https://doi.org/10.1016/j.proeng.2015.07.087

[10] A. Glinicka, M. Kruk, Analiza eksperymentalna wyboczenia niesprężystego prętów stalowych poddanych korozji w komorze mgły solnej. Drogi i Mosty 3 (2010), pp. 5- 27.

[11] A. Glinicka, M. Maciagg, Reduction of the bearing capacity of a thin- walled steel beamcolumn as a result of uniform corrosion, MATEC Web of Conferences 196, 01046 (2018), XXVII R-S-P seminar 2018, Theoretical Foundation of Civil Engineering. https://doi.org/10.1051/matecconf/201819601046

[12] K. Wasilewska, A. Glinicka, Próba ściskania rur ze stali nierdzewnej poddanych działaniu środowisk agresywnych. Logistyka 3 (2012), pp. 2375 - 2381.

[13] Instrukcja obsługi programu BlueHill v.2.6, Instron Corporation, Copyright, (2004). 